International Journal of Current Advanced Research

ISSN: O: 2319-6475, ISSN: P: 2319 - 6505, Impact Factor: SJIF: 5.995

Available Online at www.journalijcar.org

Volume 6; Issue 3; March 2017; Page No. 2724-2725

DOI: http://dx.doi.org/10.24327/ijcar.2017.2725.0089

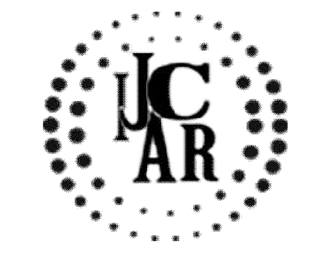

Review Article

\title{
COMPARISON OF PERIODONTOPATHOGENS AND DETECTION OF TETRACYCLINE RESISTANCE GENES BY PCR
}

\author{
Sri Vasavi Kadiyala ${ }^{1}$ and Gopinath $\mathrm{P}^{2 *}$ \\ ${ }^{1}$ BDS 3rd year, Saveetha Dental College, Chennai \\ 2Department of Microbiology, Saveetha Dental College, Chennai
}

\section{A R T I C L E I N F O}

\section{Article History:}

Received $20^{\text {th }}$ December, 2016

Received in revised form $24^{\text {th }}$ January, 2017

Accepted $6^{\text {th }}$ February, 2017

Published online $28^{\text {th }}$ March, 2017

\section{Key words:}

Periodontopathogens, Chronic Periodontitis, Aggressive Periodontitis, Tetracycline, Pcr

\begin{abstract}
A B S T R A C T
Periodontal disease is the result of an imbalance in the microbial ecology of the oral cavity, and it also depends on host susceptibility.[1] Studies have shown a close association between periodontitis and the presence of a specific group of microorganisms, mainly Porphyromonasgingivalis, Aggregatibacter, Actinomycetemcomitans, Treponema denticola and Tannerella forsythia. Thus, this study is to compare the periodontopathogens and to detect the tetracycline resistance genes by PCR among patients with different periodontal conditions. In our study, $\mathrm{T}$. forsythia was the most frequently detected pathogen in $5 / 5(100 \%)$ chronic periodontitis and $4 / 5(80 \%)$ aggressive periodontitis patients. A. actinomycetemcomitans was the least detected pathogen as it detected only one sample of chronic periodontitis case. Upon subjected them to tetracycline resistance gene (TetM gene), all were negative. T. forsythia and A. actinomycetemcomitans were the most frequently and least detected periodontic pathogens respectively. Tetracycline resistance was not observed in our isolates. This study reveals the knowledge on the prevalence of periopathogens and tetracycline resistance gene in our region.
\end{abstract}

Copyright $₫ 2017$ Sri Vasavi Kadiyala and Gopinath P. This is an open access article distributed under the Creative Commons Attribution License, which permits unrestricted use, distribution, and reproduction in any medium, provided the original work is properly cited.

\section{INTRODUCTION}

Periodontal disease is the result of an imbalance in the microbial ecology of the oral cavity, and it also depends on host susceptibility.[1] Studies have shown a close association between periodontitis and the presence of a specific group of microorganisms,

Aggregatibacter, mainly Porphyromonasgingivalis, Actinomycetemcomitans, Treponema denticola and Tannerella forsythia $[1,2]$. Recent studies have reported periodontal pathogens resistant to different antibiotics, with percentages that vary according to the populations studied, this could be due to the lack of control over antibiotic use and to poor patient treatment compliance in certain countries [3]. Tetracycline and some of its derivatives have been widely used as adjuvants in the treatment of periodontitis, both topically and systemically. $[4,5]$. Thus, this study is to compare the periodontopathogens and to detect the tetracycline resistance genes by PCR among patients with different periodontal conditions.

\section{MATERIALS AND METHODS}

Five subgingivalsamples from each periodonticcases which includes chronic periodontitis and aggressive periodontitis as well as healthy population were subjected to $16 \mathrm{~s}$ rDNA

*Corresponding author: Gopinath P

Department of Microbiology, Saveetha Dental College, Chennai analysis for P. gingivalis, T. denticola, T. forsythia, A. actinomycetemcomitans, P. intermedia and Eikenellacorrodens followed by the detection of tetracycline resistance genes (TetM) by PCR as per the following cyclic condition. Detection of the gene was carried out using primer as depicted in table 1. Bacterial DNA was extracted by boiling lysis method. $1 \mu \mathrm{L}$ of DNA extract was used as template for $\mathrm{PCR}$ reaction. The reaction mixture contained $2 \mathrm{mM}$ of $\mathrm{Mgcl}_{2} 0.2 \mathrm{mM}$ dNTP mix and $0.5 \mu \mathrm{M}$ of can gene with IU of Taq polymerase (New England Biolabs) in a 1x PCR buffered reaction. A positive control of $\mathrm{S}$. aureus with cna gene was also included in this study. PCR amplification was carried out using thermal cycler (Eppendorf) with the following cycling condition. Initial denaturation at $97^{\circ} \mathrm{C}$ for $1 \mathrm{~min}$ and 35 cycles for $30 \mathrm{~s}, 54^{\circ} \mathrm{C}$ for $1 \mathrm{~min}$ and $74^{\circ} \mathrm{C}$ for $1 \mathrm{~min}$, followed by a final extension of $10 \mathrm{~min}$ at $72^{\circ} \mathrm{C}$. PCR products were resolved in $1.5 \%$ agarose gel. A $100 \mathrm{bp}$ ladder was including in all the gel analysis.[6]

Five subgingivalsamples from each periodonticcaseswhich includes chronic periodontitis and aggressive periodontitis as well as healthy population were subjected to $16 \mathrm{~s}$ rDNAanalysis for P. gingivalis, T. denticola, T. forsythia, A. actinomycetemcomitans, P. intermedia and Eikenellacorrodens followed by the detection of tetracycline resistance genes (TetM) by PCR as described elsewhere. The amplicons were resolved in $4 \%$ agarose gel electrophoresis and findings were compared. 
Table 1 Gene sequencing of $b l a_{\mathrm{NDM}-1}$ gene

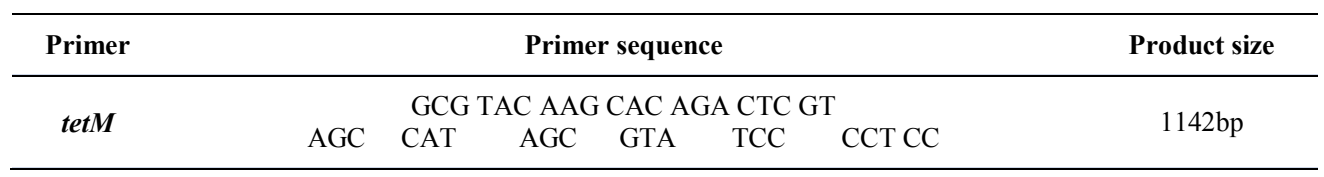

\section{RESULTS}

In our study, $\mathrm{T}$. forsythia was the most frequently detected pathogen in $5 / 5(100 \%)$ chronic periodontitisand $4 / 5(80 \%)$ aggressive periodontitis patients. A. actinomycetemcomitans was the least detected pathogen as it detected only one sample of chronic periodontitis case. Upon subjected them to tetracycline resistance gene (TetM gene), all were negative.

\section{DISCUSSION}

In this cross-sectional study, we used PCR to determine the prevalence of nine periodontopathogens in the subgingival microbiota of patients diagnosed as healthy gingivitis, CP and AgP. Study conducted by Collins and coworkers in 2016 have demonstrated that, $63.6 \%$ of P. micra, $54.5 \%$ of $\mathrm{T}$. forsythia, $45.4 \% \mathrm{~F}$. nucleatum and E. corrodens and followed by other periopathogens isolated from healthy population. Whereas, in case of chronic periodontitis cases, T. forsythia $(96.7 \%)$ scored the first predominant pathogen and in case of aggressive periodontitis cases, Both $\mathrm{F}$. nucleatum and $\mathrm{T}$. denticola were the most identified bacteria. [6]

In contrast to their study, we found $\mathrm{T}$. forsythia was the most frequently detected pathogen in 5/5 (100\%) chronic periodontitis and $4 / 5(80 \%)$ aggressive periodontitis patients. A. actinomycetemcomitans was the least detected pathogen as it detected only one sample of chronic periodontitis case.

\section{CONCLUSION}

T. forsythia and A. actinomycetemcomitans were the most frequently and least detected periodontic pathogens respectively. Tetracycline resistance was not observed in our isolates. This study reveals the knowledge on the prevalence of periopathogens and tetracycline resistance gene in our region.

\section{References}

1. Socransky SS, Haffajee AD. 2005. Periodontal microbial ecology. Periodontol. 38. 135-187.

2. Rylev M, Kilian M. 2008. Prevalence and distribution of principal periodontal pathogens worldwide. J Clin Periodontol. 35. 346-361.

3. Genco RJ, Borgnakke WS. 2013. Risk factors for periodontal disease. Periodontol. 62.59-94.

4. Chopra I, Roberts M. 2001. Tetracycline antibiotics: mode of action, applications, molecular biology, and epidemiology of bacterial resistance. Microbiol Mol Biol Rev 65.232-260 22.

5. Herrera D, Alonso B, León R, Roldán S, Sanz M. 2008. Antimicrobial therapy in periodontitis: the use of systemic antimicrobials against the subgingival biofilm. J Clin Periodontol. 35. 45- 66.

6. Collins JR, Arrendondo A, Rosa A, Valdez Y. 2016. Periodontal pathogens and tetracycline resistance genes in subgingival biofilm of periodontally healthy and diseased Dominican adults. Clin Oral Invest. 20. 349356.

\section{Please cite this article in press as:}

Sri Vasavi Kadiyala and Gopinath P (2017), Comparison of Periodontopathogens and Detection of Tetracycline Resistance Genes By Pcr, International Journal of Current Advanced Research, 6(3), pp. 2724-2725. http://dx.doi.org/10.24327/ijcar.2017. 2725.0089 